\title{
Field evidence suggests that the Palaeoproterozoic Gowganda Formation in Canada is non-glacial in origin
}

\author{
Mats O. Molén \\ Umeå FoU, Vallmov. 61, 90352 Umeå, Sweden; e-mail: mats.extra@gmail.com
}

\begin{abstract}
During more than a century since its original identification, the Gowganda Formation in Ontario (Canada) has gradually been reinterpreted from representing mainly subglacial tillites to secondary gravity flow and glaciomarine deposits. The main pieces of geological evidence advanced in favour of glaciation in recent articles are outsized clasts that have been interpreted as dropstones and patches of diamictites in a single small-sized area at Cobalt which is still interpreted as displaying subglacial basal tillites. The present research considers field evidence in the Gowganda Formation in the light of more recent work on gravity flows linked to tectonics. Detailed studies have demonstrated that the clasts which are interpreted to be dropstones rarely penetrate laminae and are commonly draped by sediments the appearance of which is similar to lonestones in gravity flows. The "subglacial area" at Cobalt displays evidence of tectonics and gravity flows, which can be traced from the underlying bedrock, and then further in the overlying sequence of diamictites and rhythmites. The sum of geological features displays appearances at odds with a primary glaciogenic origin, and there is no unequivocal evidence present of glaciation. The data indicate deposition by non-glaciogenic gravity flows, including cohesive debris flows for the more compact units, probably triggered by tectonic displacements.
\end{abstract}

Key words: Debris flow, lonestone vs dropstone, lamination vs varve, non-glacial diamictite vs tillite, Snowball Earth

\section{Introduction}

\subsection{Definitions}

Lonestone is a non-genetic term for an outsized clast in a finer matrix. This clast may have been dropped or transported by any agent, e.g., ice or a gravity flow. Dropstone is a genetic label for a clast that has dropped from a transporting agent, commonly ice. The label "dropstone" refers to outsized clasts which have been interpreted in the literature to have dropped from ice, so as to indicate that this interpretation may not be valid (definitions as of Neuendorf et al., 2005).

\subsection{History of research and changing interpretations}

In 1974 Schermerhorn published a classic paper on diamictites by comparing recent glaciogenic formations, gravity flow deposits and diamictites (Schermerhorn, 1974), which has helped geologists to recognise the gravity flow parts of many tillites. In the early 20th century many diamictites were classified as tillites, partially because knowledge of gravity flow deposits was non existent or very limited. Even today many geologists are unaware of the great impact of gravity flows (Shanmugam, 2016). Hence, 
diamictites have often been regarded as tillites, or at least as having originated from glaciogenic processes, without thorough consideration of other possible interpretations. This inference has often been based on hypotheses of palaeoclimatic interpretations (see e.g., Jensen \& Wulff-Pedersen, 1997; Arnaud \& Eyles, 2004; Eyles \& Januszczak, 2007; Carto \& Eyles, 2012; Kennedy \& Eyles, 2021), followed by association and interpretation of diamictite deposits displaying matrix-supported clasts (note: some geologists also label mixtures of sediment which are clast-supported as diamictite), striated pavements and presence of supposed dropstones as glaciogenic. If a research area was originally considered to have been influenced by glaciers, the geomorphological, depositional and deformational data from nearby outcrops were often, by default, interpreted on the basis of that scenario.

In 1908 Coleman proposed a glacial origin for diamictites in the Gowganda Formation (Fig. 1) of the Huronian Supergroup (Coleman, 1908). Since that time, the glaciogenic interpretation of this formation and other, older formations in the area has been the dominant paradigm. Many researchers refer to the hypothesis of Snowball Earth, for which the Gowganda Formation is an important area in worldwide correlations (Young, 2013, 2014). However, the evidence for Snowball Earth scenarios is equivocal, as has been confirmed by detailed dating of outcrops of Neoproterozoic (Le Heron et al., 2020) and Palaeoproterozoic strata, including the Gowganda Formation (Kump et al., 2013; Young, 2014, 2019), by the geochemical record (Bahlburg \& Dobrzinski, 2011; Bristow et al., 2011; Grotzinger et al., 2011; Zimmermann et al., 2011), including (mainly for Neoproterozoic and younger strata) ikaites/glendonites - the minerals that are supposed to be stable only in cold temperatures (Aspler et al., 2001; Hoffman, 2013; Fairchild et al., 2016), but are documented to have formed in temperate and even tropical waters (Popov et al., 2019) and, lastly, by numerous studies of the geology of Precambrian diamictites (e.g., Eyles, 1993; Molén, 2017; Kennedy et al., 2019; Kennedy \& Eyles, 2021).

The formations in the Huronian Supergroup (Fig. 1) which have been interpreted as glaciogenic are the Gowganda, Ramsay Lake, Pecors and Bruce formations, which are situated north of Lake $\mathrm{Hu}$ ron in Ontario (Young, 2013), deposits in Michigan (Beh \& Fralick, 2013) and a few smaller areas (Melezhik et al., 2013; Young, 2014, 2018). These units, especially the Gowganda Formation, are commonly described as the best documented of all Middle Precambrian glaciogenic deposits (Melezhik et al., 2013). The Gowganda Formation is almost like a "golden spike" for the Palaeoproterozoic, because it is considered to be a unique case for a cold-climate interpretation, apart from its sedimentological context (Young, 2014). However, as more detailed studies have been performed, most of the geological features in these formations have been reinterpreted as not being primarily glaciogenic, i.e., not continental tillites and varved argillites (Miall, 1985), but rather as redeposited ice-marginal glaciogenic formations (e.g., Crowell, 1964; Frarey, 1977; Card, 1978; Young, 1981; Miall, 1983, 1985; Eyles et al., 1985; Young \& Nesbitt, 1985; Fralick \& Miall, 1989; Menzies, 2000; Bennett, 2006; Melezhik et al., 2013; Young, 2019). Yet still, even in strata which have been interpreted as resedimented glaciogenic or glaciomarine clasts, there is no documented evidence of the multitude of geological features produced in the glaciomarine environment of the Quaternary, e.g., many different linear, transverse and circular formations and inclusive of iceberg scour features (Dowdeswell et al., 2016), even though at least some of the Huronian outcrop areas have been interpreted to be shallow marine and would be ideal areas for glaciomarine geological features (Melezhik et al., 2013; Young,

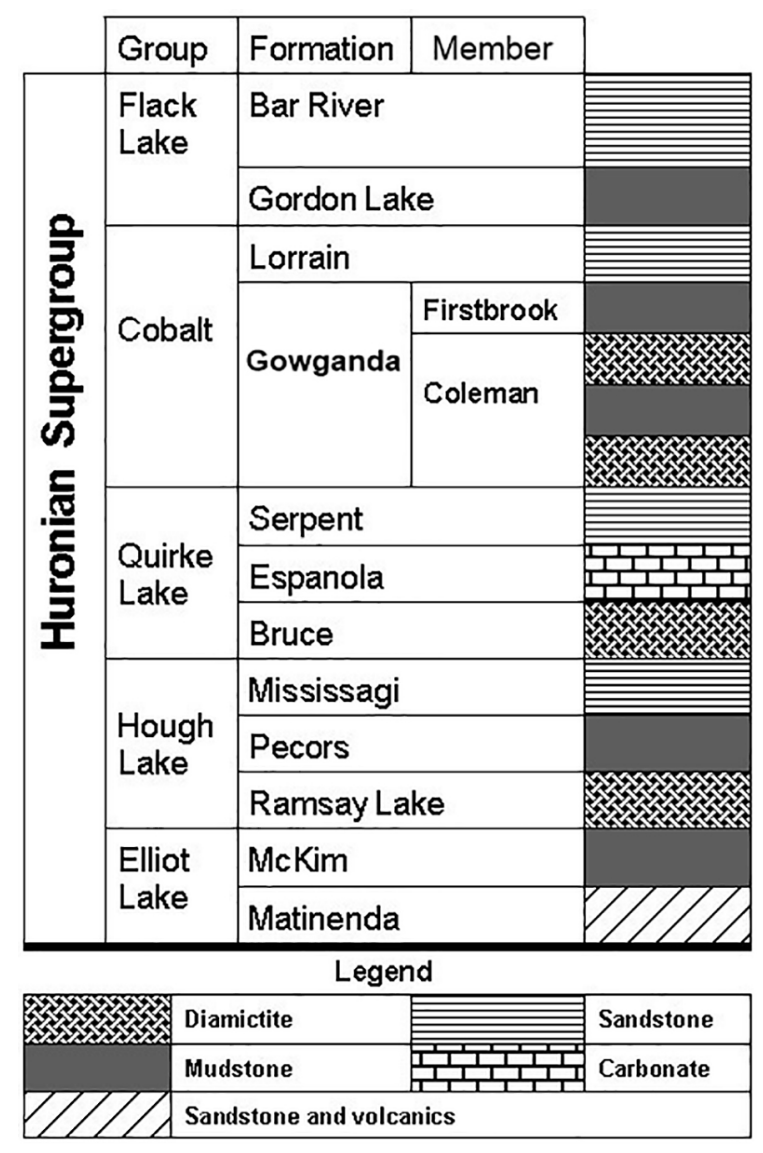

Fig. 1. Simplified stratigraphical chart of Huronian Supergroup (modified after Al-Hashim \& Corcoran, 2021). 
2019). Apart from the "dropstones", other sedimentary features, including debris flows and turbidities, have been interpreted to have been formed in a glaciomarine or glaciolacustrine environment by association and not because these display unequivocal proxies of glaciation.

There are a number of criteria for characterising a till, but most of these may be displayed by co- hesive gravity flows (Schermerhorn, 1974; Molén, 2017, 2021), for example striations produced on clasts by gravity flows and glaciers are difficult to differentiate (Atkins, 2003, 2004). In short, if there are systematic sedimentary regularities or patterns in a diamictite, it may be possible to consider if outcropping rocks were produced by a gravity flow or a glacier. These regularities may be the size of
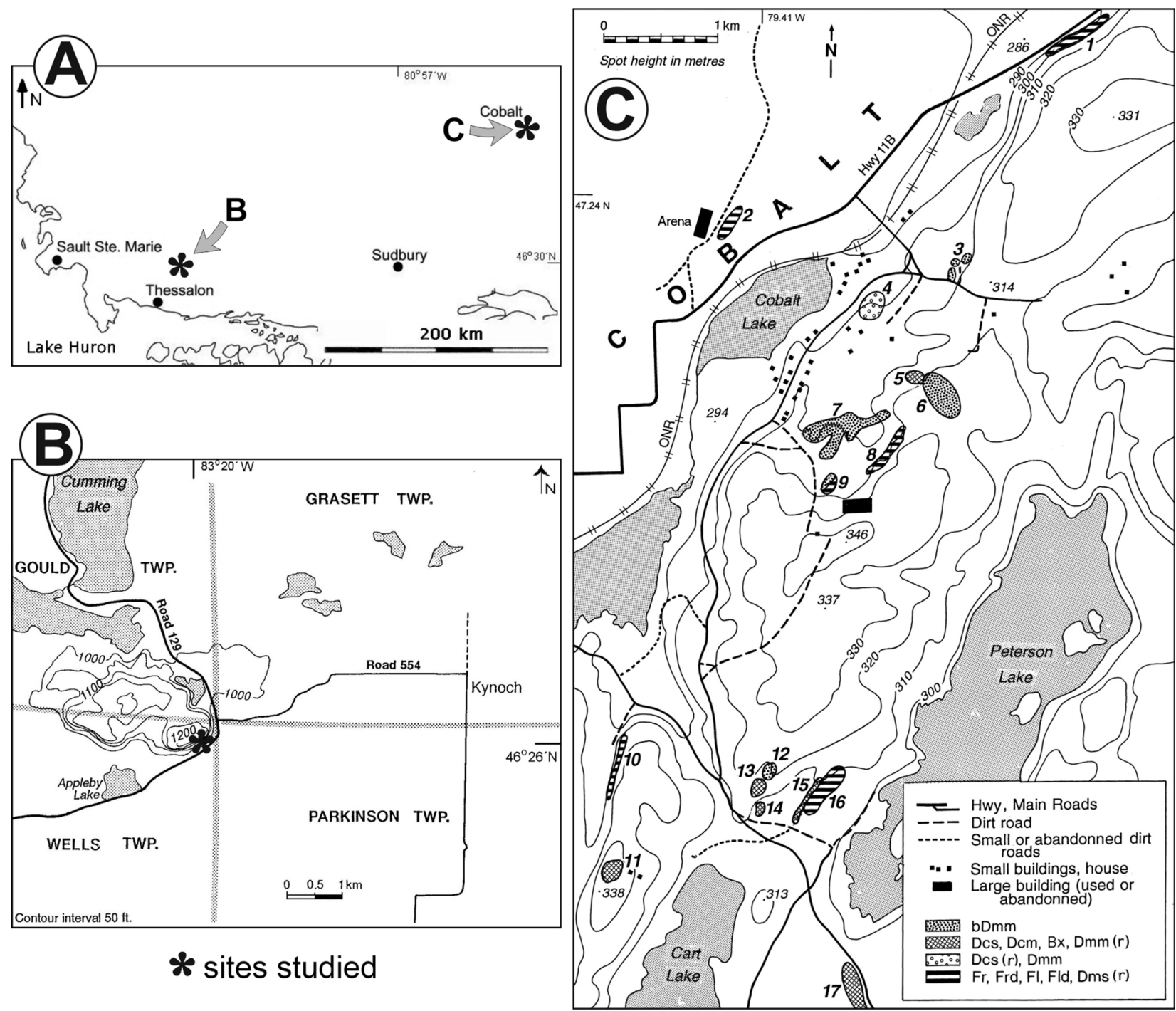

Fig. 2. A - Overview map of the southern part of northern Ontario, Canada; B - Close up map shows a well-known geological site at highway junction 129/554, c. $30 \mathrm{~km}$ north-north-east of Thessalon, where the appearance of lonestones was documented in detail for the present paper; C - Next to the small town of Cobalt there is a small area which is the only place in the Gowganda Formation which is still interpreted to be basal tillite, here shown as a detailed outcrop map. The map displaying marked outcrops at Cobalt are referred to in the text (section Results) and are the more outstanding outcrops of those mapped in detail by Mustard (1985) where it was possible to make any unequivocal detailed interpretations of the geological structures. The legend follows Eyles et al. (1983), and interpretations are those by Mustard (1985). Abbreviations: bDmm = basal diamictite (tillite), matrix-supported, massive; Dmm = matrix-supported, massive diamictite; Dms = matrix-supported, stratified diamictite; Dcm = clast-supported, massive diamictite; Dcs = clast-supported, stratified diamictite; Fr = rhythmically laminated, silt, clay $/ \mathrm{mud} ; \mathrm{Fl}=$ laminated, non-rhythmically, silt, clay/mud; $d=$ dropstones (i.e., $d$ are lonestones); $(r)=$ resedimented. Description of field sites: $1=$ Frd, $2=$ Fld-Dms(r), $3=$ bDmm, $4=$ Dmm and Dcs(r), $5=$ Dcm, $6=$ bDmm, $7=b D m m, 8=$ Fr, $9=$ bDmm and Fr, $10=$ Fr, $11=$ Dcs, $12=$ bDmm, $13=$ Dcm-Dcs, $14=$ Dcs, $15=$ Dmm(r)-Dcm, $16=$ Fr, $17=$ Dcs. 
clasts, a correlation between clast size and thickness of sedimentary strata and sedimentary structures. Diagnostic criteria were described by Schermerhorn (1974), but also in much more recent literature concerning diamictites (e.g., Kennedy \& Eyles, 2021; Molén, 2021). Varves can only be diagnosed with certainty if these display evidence of yearly deposition, but laminated formations can form diurnally from tidal water and in turbidites (e.g., Eyles \& Januszczak, 2007; Shanmugam, 2016; Smith \& Bailey, 2018). Dropstones and clasts transported within gravity flows can be diagnosed only if there are visible sedimentary structures which can be examined, like a disturbance of sediments or penetration of laminae (e.g., Thomas \& Connell, 1985; Kennedy \& Eyles, 2021), but an outsized clast in massive sediment may always be interpreted either as transported enclosed within a gravity flow or by ice and deposited as a dropstone.

Criteria relevant for the interpretation of the origin of outcropping rocks examined in the present paper are described in the following subsections.

Examples of specific "glaciogenic" features in the Gowganda Formation which, upon more detailed examination have been reinterpreted as non-glaciogenic and produced by gravity flows or tectonics, are: 1) fabrics which commonly display deviations from glaciogenic fabrics in different beds in deposits which have been interpreted as tillites (Lindsey, 1969), or follow the palaeoslope (Young, 1981) (which is evidence for deposition by gravity flows; Lindsay, 1968), 2) so-called flat-iron "glacially shaped" clasts, which are slightly concave or convex "para-flat", with many small protuberances showing that they cannot have been shaped by glaciers (Miall, 1985), 3) striated pavements and boulders which are probably of tectonic origin (Bielenstein \& Eisbacher, 1969; Harker \& Giegengack, 1989; Miall, 1985), and 4) evidence of an upper limit of clast size in at least some beds in the Gowganda Formation which is not a proxy for glaciation (Frarey, 1977).

\subsection{General geology of the Gowganda Formation}

The Gowganda Formation varies in thickness commonly between hundreds of metres to 1,600 m, and even 3,000 $\mathrm{m}$ in one area, but the majority of its rocks contain no physical evidence of glaciation (Melezhik et al., 2013). There is only one locality in the Huronian Supergroup which remains unchallenged by some researchers when it comes to the interpretation of a subglacial origin of the outcrops, including the Gowganda, Ramsay Lake and Bruce formations (Eyles, 1993). This is a "basal tillite" described by Mustard \& Donaldson (1987a, 1987b) from an area of around $10 \mathrm{~km}^{2}$ surrounding the town of Cobalt, Ontario (Fig. 2). The subglacial interpretation of this area is accepted by some authors, amongst whom are Feng et al. (2000). If the glaciogenic origin of this deposit is substantiated, then interpretations of other parts of the Gowganda Formation as resedimented glaciogenic debris may still be vindicated. If the glaciogenic origin cannot be substantiated, the resedimented debris may equally well, or better, be interpreted as non-glaciogenic, except if there are non-equivocal geological features indicative of a glacial component in the deposits.

In general, the stratigraphy of the Gowganda Formation is very complex (e.g., Frarey, 1977; Miall, 1983; Melezhik et al., 2013). The deposits are commonly scattered and discontinuous, laminated and stratified, but sometimes massive (Mustard \& Donaldson, 1987b; Melezhik et al., 2013). The main deposits cover an area of approximately $250 \times 350$ $\mathrm{km}$, but the maximum areal extent of the glaciation is considered to have stretched over millions of square kilometres (Mustard \& Donaldson, 1987b; Young, 2018). But, as these lower Proterozoic rocks are heavily eroded, their original extent and continuity cannot be determined.

\section{Methodology and research area}

The current work is not concerned with the previously described general geology and stratigraphy of the Huronian Supergroup, including the Gowganda Formation, nor with the diamictite outcrops which have been reinterpreted as redeposited or not primarily glaciogenic. The general geology has been described in detail by others, and does not need to be repeated here (e.g., Miall, 1983, 1985; Young \& Nesbitt, 1985; Mustard \& Donaldson, 1987a). The only geological structures that are examined in the present work are the sedimentological and erosional features which are supposed to be, more or less, definitive evidence for glaciation. Hence, any "reworked" or other material which is supposed to exhibit no unequivocal evidence of direct contact with glacier ice is not of concern for the present paper, since these sediments do not demand glaciation per se.

In order to find localities which have been interpreted to be primarily glaciogenic, a literature search concerning deposits of the Gowganda Formation was performed. Outcrops for which documented evidence seemed not be at odds with the 
current interpretation of direct deposition from glaciers were selected for more detailed field work, in order to find evidence of glaciogenic and/or gravity flow origin. General geological features, and those that are not at odds with earlier reports, were not documented as there is no need to repeat published data.

The two probably most outstanding "glaciogenic" localities in the Gowganda Formation are the classic "varvites" at a steep rock face $c .30 \mathrm{~km}$ north-north-east of Thessalon, Ontario (co-ordinates: $46^{\circ} 26^{\prime} \mathrm{N} ; 83^{\circ} 20^{\prime} \mathrm{W}$, c. $50 \mathrm{~m}$ west of Highway 129 and around $500 \mathrm{~m}$ south-west of the junction with Highway 554; hereafter junction 129/554) and a small area of approximately $10 \mathrm{~km}^{2}$ in the Coleman Member at Cobalt, Ontario (co-ordinates: $47^{\circ}$ $24^{\prime} \mathrm{N} ; 79^{\circ} 41^{\prime} \mathrm{W}$ ) (Fig. 2). The Coleman Member at Cobalt is the only area which is still interpreted as a basal tillite in the Gowganda Formation, but it also displays "varvites" with lonestones. Other areas in the Gowganda Formation have long since been reinterpreted as not subglacially formed, but mainly resedimented, by probably all researchers and are not of concern for the present study (Feng et al., 2000; Melezhik et al., 2013).

The outcrop at junction 129/554 measures in total approximately $50 \mathrm{~m}$ in height and $900 \mathrm{~m}$ in length (Howe, 2015). Yet, only a smaller part of this outcrop, composed of laminated beds containing lonestones, could be examined (approximately $2 \times 100 \mathrm{~m}$ ), and there were only few outsized clasts where sedimentary structures could be examined.

The Cobalt area comprises many small outcrops of both diamictites and rhythmic sediments displaying outsized clasts, which are laterally spread out. The diamictites which have been interpreted to have formed subglacially would be expected to display clear evidence of glaciation. However, many of the outcrops at Cobalt were so small and/or covered with Pleistocene till or tree roots, that it was impossible to find any diagnostic features. All outcrops were thin, at most a few metres, but almost always less than one metre vertically. All outcrops which showed sedimentary structures, except for only "clasts in a matrix", or those that covered larger areas, were examined. Only features which could be examined in detail and had been described as glaciogenic in origin previously have been studied. Single small outcrops with no diagnostic features have not been examined. The outcrops selected have been interpreted to be varves with dropstones and basal/lodgement tillite and also display more than general geological features.

\section{Results}

\subsection{Are lonestones dropstones?}

\subsubsection{The site at junction $129 / 554$}

There is a classic lonestone-bearing rhythmite sequence in the Gowganda Formation, which crops out just southwest of junction 129/554, and is easily accessible (Miall, 1985). The section is commonly interpreted to be a varve sequence with dropstones, but there are almost no clasts $>1 \mathrm{~cm}$ in diameter. A detailed study of the clasts at outcrop, supposed to be dropstones, show that laminae commonly have not been penetrated but are in most cases draped all around the clasts. The laminae below lonestones are commonly only slightly bent. Those above and below regularly thin out, but laminae closer to the clasts regularly thicken, and often surround the clasts on all sides (Fig. 3). Dispersed and smeared clots of coarse material are also present in the sequence.

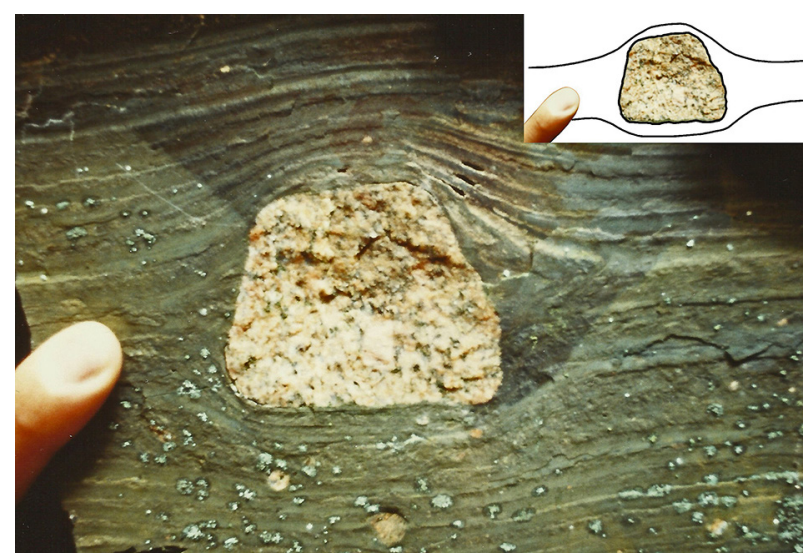

Fig. 3. A clast which is commonly interpreted to be a dropstone, within the rhythmites which commonly are interpreted as a varve sequence (junction 129/554). The lonestone is deposited in a thick layer which thickens closer to the clast and surrounds the clast both above and below. The laminae below are only slightly bent, which indicates compression. The laminae are laterally disturbed a few centimetres around the clast, and continue as a thicker band on the left side of the clast (see line drawing). The full appearance of the sediments and the clast indicate simultaneous lateral movement of clast within the sediments during deposition, and not deposition of the clast from above or transported on a sediment surface. Also note that the laminae are subdivided into thinner "sub-laminae", indicating sorting in a mm-scale and segregation of silt and clay by bottom currents. The small holes above the upper right-hand corner of the clast may be the result of differential weathering, which could indicate that the sediment was less compressed on one side of the clast. A picture of exactly the same clast was published by Melezhik et al. (2013, fig. 7.6a), as a "dropstone", but with no additional geological information or discussion. 


\subsubsection{Cobalt area}

In the Cobalt area, lonestones which have been interpreted to be dropstones, commonly are more abundant in coarse-grained than in fine-grained rhythmites (Mustard \& Donaldson, 1987a). During the field work only lonestones in fine-grained rhythmites, supposed to be varves, were systemat-

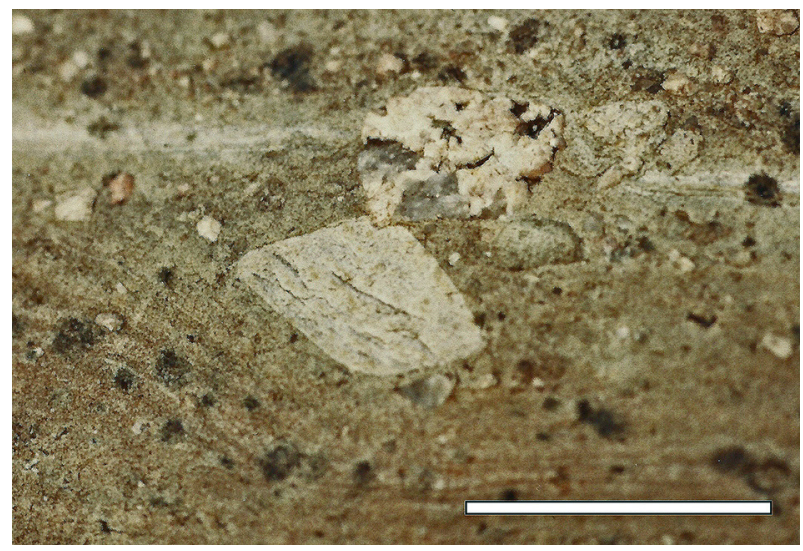

Fig. 4. A granitic lonestone pressed down into another lonestone, which is a soft-sediment (rip-up) clast of sandstone. Also note that the upper lonestone "penetrates" the light, coarse- grained layer without disturbing the bedding. Scale bar equals c. $5 \mathrm{~cm}$ (Site 2).

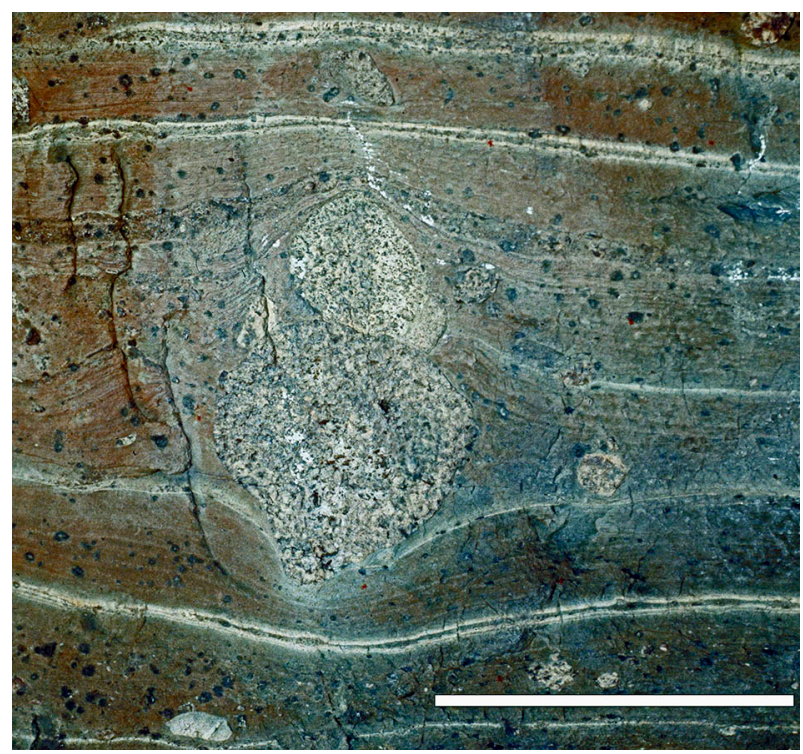

Fig. 5. These so-called "dropstones" are in what has been interpreted as a non-rhythmically laminated deposit (Fld). However, these are two lonestones which are piled up on top of each other. The layer containing the lonestones is thicker and the lamina below not penetrated but only bent. Actually, to the left of the lonestones there is only a single thick layer, which then to the right of the lonestones turns into one lamina of light coarser grains and an extra darker layer with the same thickness as most other layers. Scale bar equals c. $10 \mathrm{~cm}$ (Site 2).
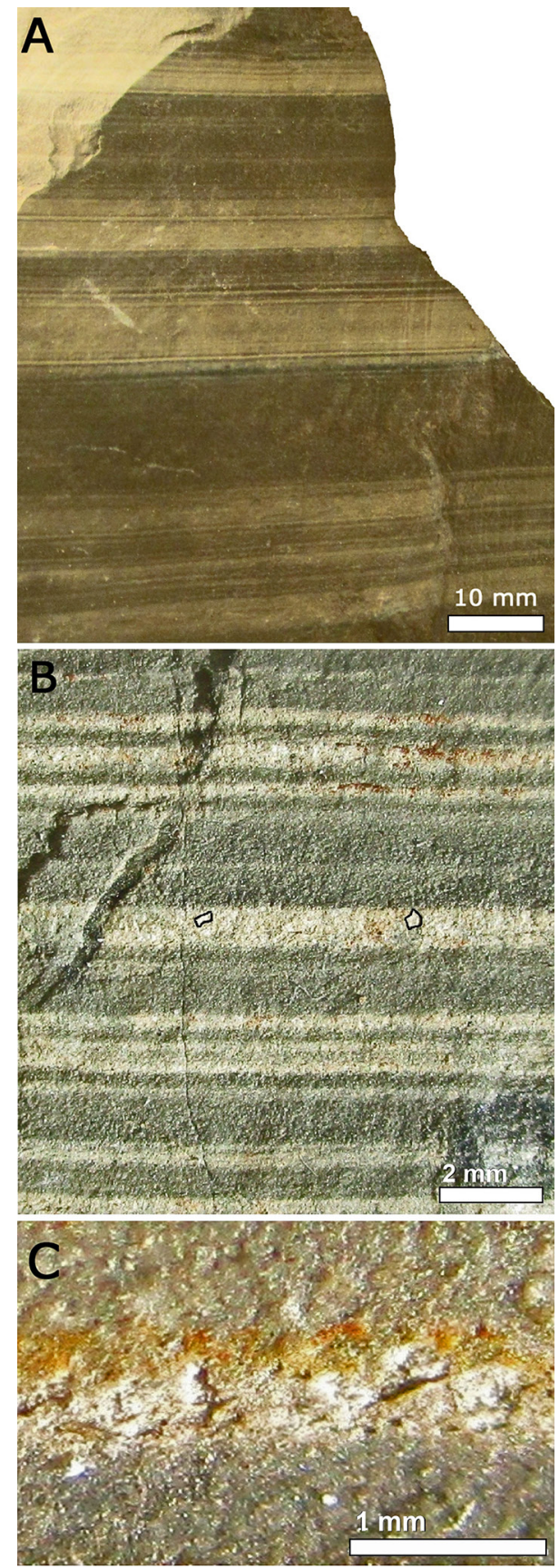

Fig. 6. A - The "varves" in the Gowganda Formation are commonly subdivided into many thin, repetitive "couplets" of very thin light layers with large grain size and thick dark layers with small grain size, displaying no evidence of periodic yearly variation; B Close-up photograph showing laminae with two light grains marked; C - Near close-up photograph showing a light lamina with large grains and dark laminae above and below (Site 1, at Cobalt). Compare with illustrations in Jackson (1965), Hughes et al. (2003), Melezhik et al. (2013), Williams et al. (2016) and especially to turbidite rhythmites described by Eyles \& Januszczak (2007, fig. 13). 
ically documented, because coarse-grained rhythmites or laminated deposits (mostly composed of sand) were not interpreted to be varves and also contained what was labelled lonestones by Mustard \& Donaldson (1987a) (up to $50 \mathrm{~cm}$ in diameter) and not as other clasts that were labelled dropstones. No lonestone from the fine-grained rhythmites was larger than $14 \times 9 \mathrm{~cm}$, and the overwhelming majority measured only $1-4 \mathrm{~cm}$ in diameter. Almost all lonestone clasts in the formations that were $>1 \mathrm{~cm}$ in diameter were measured, i.e., a total number of 60 clasts, and especially larger clasts were searched for. Most of these lonestones are therefore classified as gravel, and these are systematically much smaller than clasts in the diamictites at Cobalt and other localities which commonly are of cobble to boulder size (see section 3.3).

The laminae below and next to the lonestones are commonly not penetrated, but are draped around the clasts, both above and below, or simply continue more or less unbroken on both sides of the clasts, thus evidencing that the clasts were deposited simultaneously with the laminae as in gravity flows. Laminae at the central level of the lonestones commonly thicken, but the laminae above and below the lonestones commonly thin out, which causes the total thickness of the laminae including the lonestones to increase. This is similar to lonestones at the junction 129/554 and to photographs of "dropstones" from the Gowganda Formation as published by, amongst others, Melezhik et al. (2013) and Kennedy (2020).

Commonly laminae containing lonestones are thicker than those without lonestones, both close to and at a distance from these clasts. If thick laminae surround lonestones, these laminae are almost unaffected by the presence of the lonestones. A few lonestones exhibit soft-sediment deformation on one side. The largest recorded lonestone $(14 \times 9 \mathrm{~cm})$ displays deformation on both sides, and the deformation on one side continues laterally for a few tens of centimetres in the same laminae, thus displaying evidence of lateral transport. Only a few clasts with very sharp edges penetrate laminae. Such is to be expected even if the clasts have been transported by gravity flows, as sharp edges easily penetrate soft layers. One granitic lonestone at site 2 (for all site numbers, see Fig. 2) was pressed into another soft (rip-up) sandstone lonestone (Fig. 4) and two others were piled up on top of each other (Fig. 5).

\subsection{Laminated sediments}

The "varves" in the Gowganda Formation commonly are subdivided into many thin strings of light and dark layers, which is evidence of frictional and/or current segregation of silt and clay by bottom currents in the lower parts of a moving water-sediment mass indicating turbidite flow and not slow deposition during a long time on a yearly basis (Yawar \& Schieber, 2017) (Fig. 6). Marine couplets, formed in response to tidal water, commonly display differences to varves, and the probably most diagnostic appearance is double mud layers (Shanmugam, 2016, 2017).

Howe et al. (2016) conducted research to find if there was any cyclicity in the "varves", at junction $129 / 554$, and at an outcrop $4 \mathrm{~km}$ northeast of this site. They recorded thin "summer" and thick "winter" lamina, as also documented by myself, which in most cases are the opposite of yearly varves (at least when this appearance is systematic). Apart from that, Howe et al. (2016) recorded climatic cyclicity which was later shown to be random and not cyclical (Smith \& Bailey, 2018).

At Cobalt, the rhythmically deposited layers display load casts and boudins (sites 8 and 10; Fig. 7), slightly discordant bedding in a few laminae (sites 1,8 and 10), thick dark and thin light laminae (opposite of varves; site 1 and 16; examples in Figs 5 and 6), a clastic sill/dike where the laminated deposits have been partly fluidised and pressed horizontally and vertically (site 1) (Fig. 8), and in one outcrop climbing ripples (site 10).

Fig. 7. Rhythmically deposited layers displaying load casts (arrows) and boudin. Scale bar equals c. $1 \mathrm{~m}$ (Site 10).

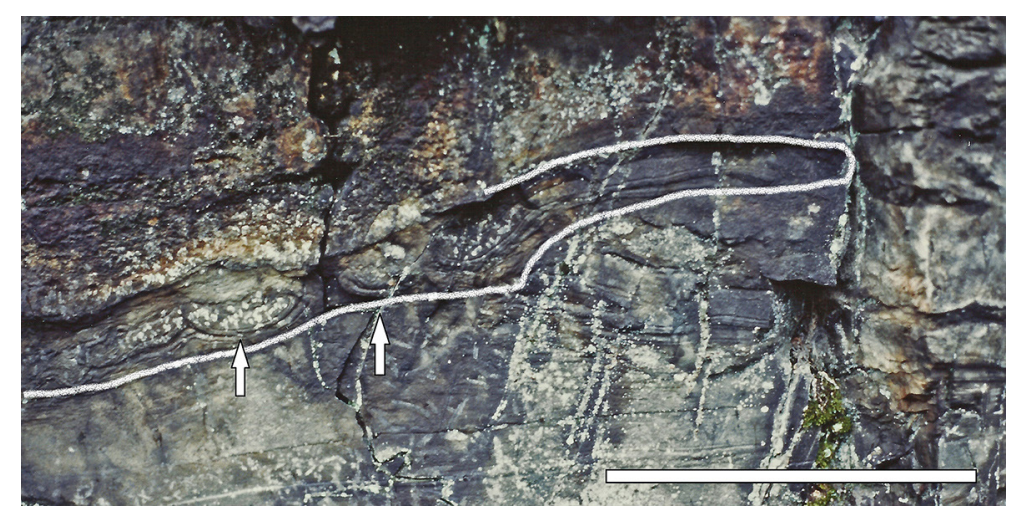




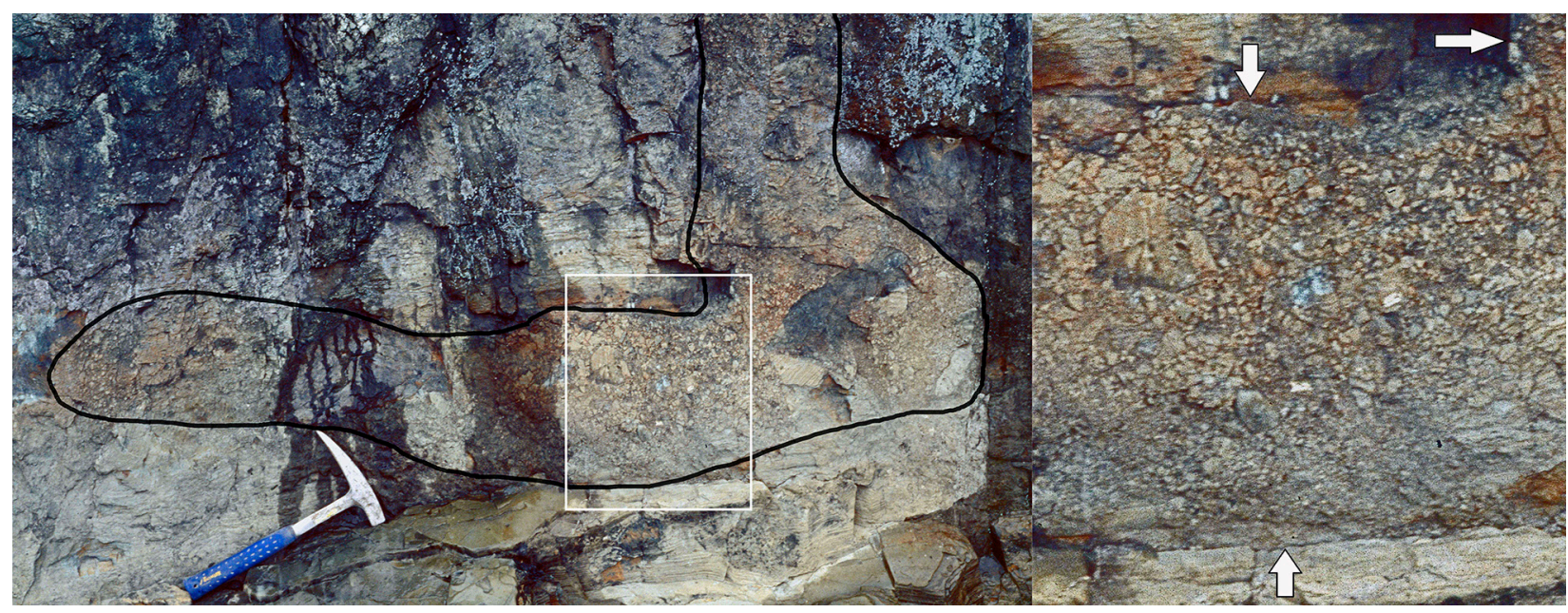

Fig. 8. Clastic sill/dike. Clastic dike is reddish brown, and consists of pieces of the laminated sediments which have been mobilised. Close-up picture is from just where the clastic dike makes a bend upwards. The upper, lower and left contacts of the dike are clearly visible (see arrows) (Site 1).

\subsection{A case study of "basal tillite" at Cobalt}

\subsubsection{General lithostratigraphy}

In the small town of Cobalt, the Gowganda Formation deposits contain the only diamictites which still are interpreted to be "basal tillites." The beds or outcrops are irregular, with commonly only one or two facies of the sedimentary sequence present in any outcrop, so there is no place where a complete facies sequence is present. However, there is a general order in the strata. The lowermost deposits at Cobalt are often breccias. This is subjacent to a clast-supported diamictite (Dcm/Dcs; definitions according to Eyles et al., 1983, and interpretations according to more detailed work by Mustard, 1985; see Fig. 2 for all definitions and interpretations) and/or is followed by a matrix-supported diamictite, which is commonly preserved in 1-2 $\mathrm{m}$ deep elongated depressions. Higher up in the sequence is a lonestone-bearing rhythmite (Mustard \& Donaldson, 1987b).

\subsubsection{Archaean bedrock}

The Archaean bedrock subjacent to the diamictites at Cobalt has been fractured, lifted and transported vertically and laterally at many places, and therefore displays an angular, sharp-edged pattern (compare Miall, 1985). The depressions or holes in

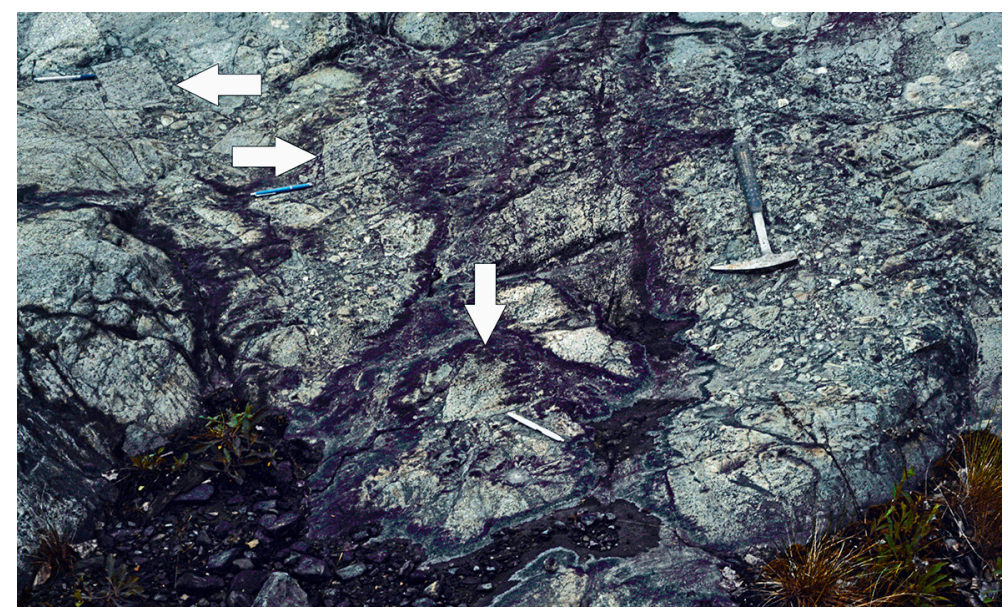

Fig. 9. Sharp-edged depression displaying non-glacial plucking and deposition. Arrows indicate blocks which can be fit into the Archaean bedrock, like a "jigsaw puzzle". In the depression, clasts have been plucked mainly on the left side (brown, darker area, filled with sediment and bedrock clasts, over and beneath vertical white arrow), while a diamict has been deposited at the right side (at hammer), indicating strong fracturing of the bedrock, short transport and quick deposition of diamictite (Site 6). 


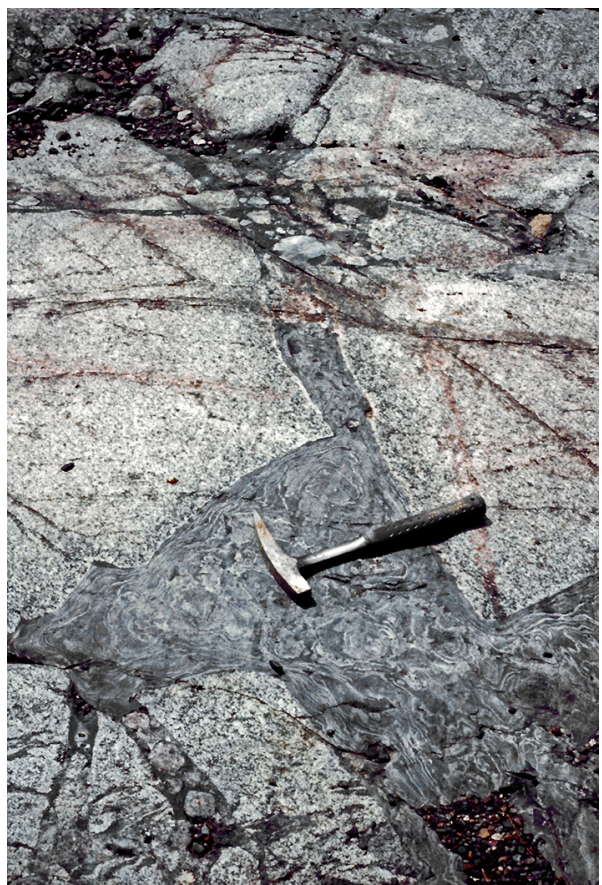

Fig. 10. Matrix/clast-supported megabreccia at site 17. Broken-up boulder, with pieces still more or less in place, i.e., displaying a "jigsaw puzzle" structure. Similar structures are common in gravity flow deposits (see text). Note banded flow structures in matrix between pieces.

the bedrock have been filled with diamictite (Figs 9-10, sites 5, 6 and 7). The bedrock contact with the "tillite" is therefore very irregular, displaying sharp-edged protuberances on a scale from a few centimetres up to more than a metre with no evidence of glacial smoothing (sites 5, 6, 7 and 12). In one depression bedrock clasts have been plucked at only one side, while a diamict formed almost entirely on the other side, indicating heavy fracturing of the bedrock, followed by short transport and subsequent deposition by a diamictite (Fig. 9, site 6). If this depression would have been glaciogenic, it would have been more probable that it had been filled with diamictite/tillite in the complete depression. In addition, there should have been evidence of glacial sculpturing/abrasion.

The basal breccia, superimposed on the bedrock, has more or less formed at all places where the contact with the underlying Archaean bedrock is visible (Fig. 2, sites 5, 6, 7 and 12). Many of the breccia clasts can be fitted into the underlying bedrock (Figs 9-10). Similar "jigsaw puzzle" structures are present in many outcrops of Gowganda Formation diamictites (Legun, 1984; Harker \& Giegengack, 1989; Kennedy, 2020).

\subsubsection{General diamict structure}

The diamictites at Cobalt consist of a mix of clasts with mainly two discrete appearances, but very few clasts with an intermediate appearance. The two appearances are: 1) more or less well rounded clasts, transported over large distances. and 2) brecciated clasts derived from underlying rocks and transported over short distances (see also Miall, 1985). The former appears to have been abraded and rounded by water for a long time, and the latter clast type is what would be expected if the bedrock fractured, for example, as a result of a strong earthquake. But none of the clast appearances are typical glaciogenic. The latter clast type also is what is present in the Archaean bedrock just below the diamictites. The clasts do not display an extensive number of features that can be referred to as evidence for strong subglacial action, such as facets or a mixture displaying all different shapes and varying degrees of abrasion and rounding subsequent to fracturing, but commonly only the mix of the two types of clasts mentioned are present.

The diamictites are sorted and consist of streaks of matrix and clast-supported beds, the latter consisting of bands of pebbles, boulders and sometimes angular clasts, supported by gravel, sand or clay (sites 4, 11, 13-15 and 17). Even the small outcrops of basal matrix-supported "tillite" contain clasts which are clustered, indicating transport in a non-rigid medium similar to a gravity flow. Whenever there are abundant clasts they commonly have diameters in excess of $25 \mathrm{~cm}$ (e.g., Fig. 10, sites 4, 11, 13-15 and 17), but in more clast-poor parts of the diamictites the clasts are commonly much smaller, again indicating internal sorting in different facies. This also holds true for the resedimented and

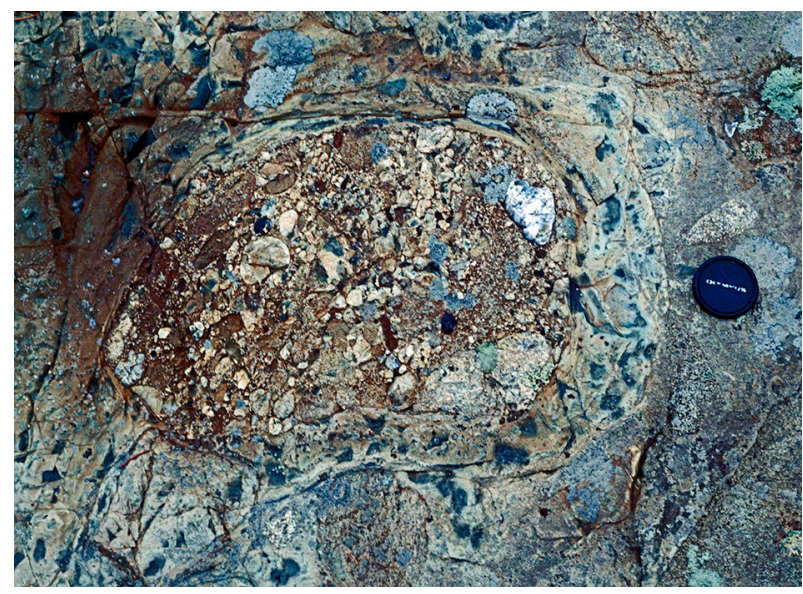

Fig. 11. Rounded diamict ball in clast-supported, resedimented diamictite. Note flow structures in lower lefthand corner and around the diamict ball, displaying the transport path (Site 15). 
clast-supported diamictites, as well as for the lower-most contact zone between the basal "tillite" and the Archaean bedrock.

Flow and slide structures are common in the "tillites" (sites 3, 5, 7, 9, 12), and these are sometimes adjacent to boulders displaying the transport path of these boulders. Some clasts in the basal clast-supported "tillite" were soft during deposition, as they have been pressed into each other. One ball of diamictite had been ripped up, rounded and deposited in another diamictite (Fig. 11, site 15, Dm$\mathrm{m}(\mathrm{r})$-Dcm), similar to a rounded ball of diamictite in the Palaeozoic of Antarctica that was deposited in a conglomerate (Lindsay, 1970).

\subsubsection{Clast-supported diamictite}

The largest clasts documented in clast-supported diamictite (Dcm/Dcs) measure $90 \times 65 \mathrm{~cm}$, $130 \times 110 \mathrm{~cm}$ (site 15) and $240 \times 190 \mathrm{~cm}$ (site 17), but large clasts in clast-supported diamictites were not searched for specifically. In streaks, where the clast-supported diamictite is poor in clasts, the only clasts present are much smaller (e.g., 5-20 cm) and commonly surrounded by flow structures, giving the deposit an appearance similar to the basal matrix-supported "tillite".

The $240 \times 190 \mathrm{~cm}$ clast and other clasts at site 17 have been crushed, but the pieces are more or less in their original place in the Archean bedrock and surrounded by the lowermost diamictite (Fig. 10). This phenomenon is not rare, but an example of how angular fragments can be added to diamictites, and there is sediment between the pieces.

\subsubsection{Matrix-supported diamictite}

The basal matrix-supported "tillite" (bDmm) is very clast-poor and the clasts are small; few clasts are larger than $10 \mathrm{~cm}$ in diameter. The largest clasts observed within the basal "tillite" are $75 \times 30 \mathrm{~cm}$ (site 6), $60 \times 50 \mathrm{~cm}$ (site 3) and $50 \times 40 \mathrm{~cm}$ (site 7), but these three are exceptional, much larger than other clasts observed in this diamictite. It is also possible that these large boulders are close to the Archean contact, and because this contact is undulating it is not clear at what depth above the bedrock surface the clasts are situated. There are large clasts at the bottom of the matrix-supported "tillite" that do not originate from the breccia, but these are commonly well rounded granites and gneisses with maximum recorded sizes of $110 \times 70$ $\mathrm{cm}, 130 \times 40+\mathrm{cm}$ (site 7) and $180 \times 130 \mathrm{~cm}$ (site 12). These large clasts are thus not deposited enclosed deeply within the "tillite" but are at the bottom, indicating that they settled down in a soft medium such as a mass flow.

\section{Discussion}

\subsection{Lonestones}

Young (in Melezhik et al., 2013, p. 1067) was not definite concerning the interpretation of lonestones and wrote, "... the most persuasive evidence of glacial influence derives from the occurrence of isolated clasts (ice-rafted dropstones?) in laminated strata". Commonly, in sedimentary sections worldwide, lonestones have been interpreted as dropstones (Tachibana, 2013; Molén, 2021), and other interpretations have not been explored. Sometimes it is possible to distinguish dropstones from lonestones transported by gravity flows, but sometimes not (Kennedy \& Eyles, 2021). Single clasts, up to 20 metres in diameter (Shanmugam, 2016), or clusters of clasts, can be dragged along, move upwards through the gravity flows and be deposited at different depths and near the top of a sedimentary sequence during single depositional events (Postma et al., 1988; Scott, 1988b; Walton \& Palmer, 1988; Best, 1992; Tachibana, 2013). Hence, lonestones are commonly found in gravity flow deposits, and this is not a rare phenomenon. One example includes clasts with diameters of up to 15 $\mathrm{cm}$ which have been transported more than $400 \mathrm{~km}$, probably by flowing water and/or gravity flows. After deposition the clasts became incorporated in local gravity flows. Formerly, the mode of transportation of these lonestones was interpreted to have been by icebergs (Jansa \& Carozzi, 1970).

The appearances of the lonestones at junction $129 / 554$ and at Cobalt are not what is commonly expected from clasts dropped directly from icebergs, but these are readily explained by gravity flow transport. Compaction of sediments will take place just from the loading pressure from sediments deposited further up in the sequence, which will compress laminae around lonestones. Also, as documented below, a detailed study of the formations has revealed sedimentary structures displaying: 1) little or no penetration by "dropstones", and, when present, commonly only at sharp corners, 2) laminae that thicken for a longer distance away from and close to, and thin above and below "dropstones", 3) evidence of lateral currents and simultaneous transport of clasts during deposition and "freezing" of the flows during the sedimentary process, 4) small size of "dropstones", 5) systematically small size of clasts compared to clast size in diamictites, and 6) correlation between the size of "dropstones" and the thickness of strata. In a glacial environment, if there are many dropstones, this could be correlated to periods of much melting of 
glaciers and deposition of thicker bottom sediments in varvites. However, there will be no correlation between the size of dropstones and sediment thickness, nor any systematic differences in size between "dropstones" and clasts in diamictites. The only possible correlation between sediment thickness and clast size is when discrete "sections" inside a gravity flow are thicker and therefore will transport larger clasts. Concerning the small size of clasts, turbidities systematically transport smaller clasts than do cohesive debris flows.

Pleistocene dropstones commonly penetrate laminae to approximately one third of their size (Thomas \& Connell, 1985), which is not the case for the lonestones deposited in the outcrops studied here. Except for the sedimentary structures connected to the lonestones, the generally small size of the lonestones in the Gowganda Formation indicates gravity flow transport, as large clasts are commonly transported by icebergs but larger clasts are not easily transported with fine-grained material without evidence of deformation. If larger clasts are transported with gravity flows, these may deform the strata both laterally and vertically, depending on flow strength and mechanical impact, as seen with the largest lonestone $(14 \times 9 \mathrm{~cm})$ recorded here and a few other larger lonestones described in the paragraph below. Lonestones in non-rhythmic layers (site 2 at Cobalt, Figs 2, 4 and 5; Fld-Dms(r) according to Mustard, 1985) commonly display the same appearance as those in rhythmically deposited layers, thus enhancing the evidence of lateral current and transport instead of dropping from icebergs.

There are very few large clasts which have been interpreted as dropstones, and these few have been photographed many times. One outsized clast is from the Pecors Formation; this is elliptical and measures c. $40 \mathrm{~cm}$ in length (Fig. 12). This clast is one of the most photographed "dropstones", and in Melezhik et al. (2013) the same clast is shown twice in their figures $7.8 \mathrm{~b}$ and $7.13 \mathrm{~b}$. The clast displays no evidence of simple penetration, but does show chaotic disturbance of all sediments surrounding all sides (sandstone displaying ripples and laminated mudstones), and a small, vertical V-shaped fault displaying intact laminae below the clast. This appearance does not indicate a clast sinking down through a water column, where there is slow deposition of laminae. The appearance of the sediments is indicative of a more energetic deposition where very soft and not fully dewatered laminae all around the clast became mixed, displaying a path of movement for the lonestone clast through the sediments. The appearance may indicate slumping at the front part of a gravity flow into soft sediments or an outrunner clast (the latter label for similar clasts was used by e.g., Martinsen, 1994). On the other hand, if we appeal to a glaciogenic interpretation, it could maybe be a clast that fell from the front of an iceberg that was grounded during low tide, with sediments that were either very soft and water soaked or with the clast penetrating with great force, the latter either indicating very shallow water or high velocity. However, the soft sediments indicate rapid deposition of laminae that had not been compacted, and there is no evidence indicating icebergs. Concerning the appearance of the lonestones in this formation, Young wrote: "... Pecors Formation contain large isolated clasts that appear to depress or penetrate underlying layers." (Melezhik et al., 2013, p. 1067; see also Kennedy, 2020).

Another outsized "dropstone", this time from the Gowganda Formation, is more spherical and

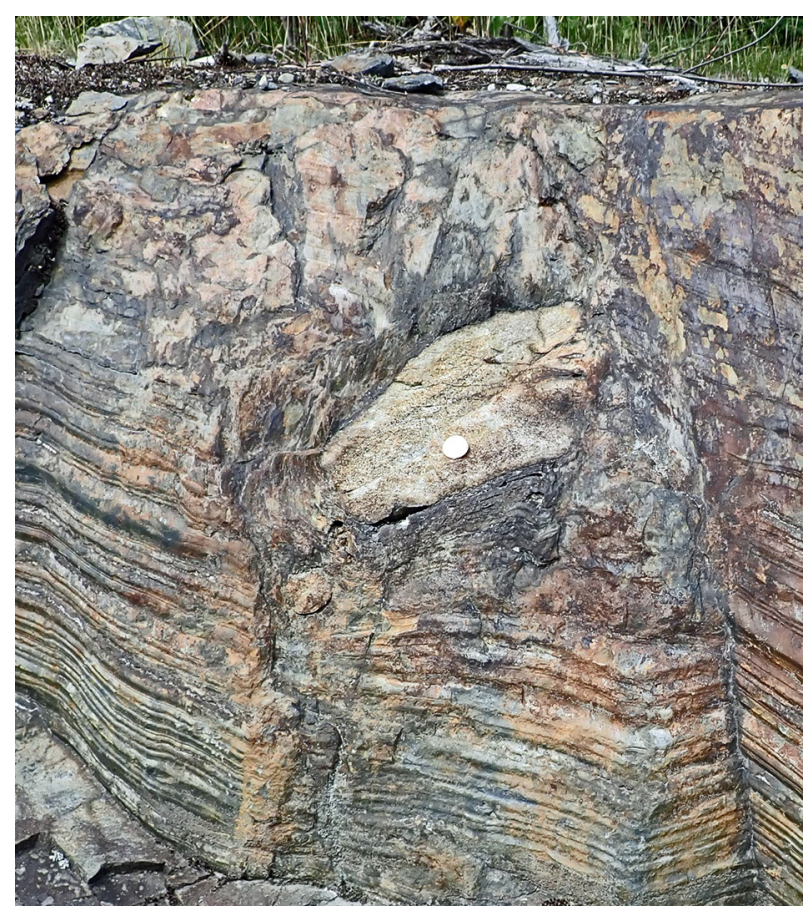

Fig. 12. Pecors "dropstone." All sedimentary structures around the clast are chaotic, i.e., they are mixed and have more or less disappeared. The appearance of the clast with surroundings display an appearance similar to when a volcanic bomb hits shallow water, or a lonestone swept away by a gravity flow and quickly sinking through sediment before compaction. The evidence is in favour of non-compacted sediments, because the sediments below the clast have been pushed downwards in a V-shaped fault. If this clast had fallen into compacted sediments, or into deep water, the sediments would not be mixed much. The complete section, including the "dropstone", appears to be an injection of a gravity flow down into the rippled sandstone (Photograph by Kirsten Kennedy; Loonie coin as scale). 
measures c. $40 \mathrm{~cm}$ in diameter (Melezhik et al., 2013, fig. $7.8 \mathrm{~d}$ ). The clast does not show much penetration of sediments but mostly compression and some lateral disturbance and infilling of sediments suggesting lateral movement. Similar interpretations concerning the origin of other large solitary clasts can be made for a lonestone, c. $50 \mathrm{~cm}$ in diameter, interpreted as a dropstone and pictured in figure 7.16d in Melezhik et al. (2013) and figure 19.1 in Young (2017), which Young (2017, p. 515) described as, "Such unusually large fragments are interpreted as 'dropstones' emplaced by glacial ice ... " (quotation marks by Young). This latter lonestone appears to have been displaced downwards into more massive soft sediments with sediment draped around the clast.

Concerning lonestones in the Gowganda Formation (in Melezhik et al., 2013, p. 1072), Young stated, “... varve-like rhythmically alternating laminae of siltstone and mudstone with isolated clasts that were probably transported by glacier ice" (my underlining). If there were glaciers or icebergs/sea ice in the area, the most conclusive evidence left of these would be clasts with, at best, an equivocal origin, i.e. dropstones. But, as documented above, the lonestones do not in general display the typical appearance of dropstones, but appear to have been dragged along by gravity flows. The few larger clasts in the formations display appearances that are not compatible with dropstones. Outsized clast in other areas have been reinterpreted as probably reworked clasts from diamictites, and Young et al. (2004, p. 70) wrote "Thus the possibility that they are glacial dropstones can be ruled out". While it cannot be demonstrated in full that any lonestone anywhere is not an occasional dropstone, the geological evidence from the Huronian Supergroup, and especially the Gowganda Formation, favours a non-glaciogenic origin.

\subsection{Laminations}

Laminated beds next to diamictites are, by association, commonly interpreted as glaciogenic rhythmites or varves, without closer inspection or discussion of different interpretations. The laminated layers described in the present paper do not display an appearance that is typical of glaciogenic varves but they are more closely similar to rhythmites deposited by turbidities (e.g., Schwab, 1981; Lowe, 1988; Domack, 1990; Eyles \& Januszczak 2007; Isbell et al., 2008; Zavala \& Arcuri, 2016), as seen from their internal structure (thickness of "winter/summer" layers, division of layers into thin sublam- inae, presence of boudins, climbing ripples, load casts and clastic dike) and the appearance of the lonestones. These features of the rhythmites in the Gowganda Formation are typical of rapidly deposited sediments, but commonly not of yearly varves. This interpretation conforms well with those by other researchers, i.e., that "varves" present in the Gowganda Formation appear to have been deposited from turbidites, and that none is a true varve (Jackson, 1965; Miall, 1983, 1985; Eyles et al., 1985; Smith \& Bailey, 2018).

\subsection{Basal diamictite}

Glaciers commonly erode the basement substantially, while gravity flows have a greater diversity of effects. Gravity flows often leave no traces but only pass areas (bypass zones), or they may be lifting sediments from the subsurface or deposit sediments (Peakall et al., 2020). The bedrock at Cobalt displays no evidence of abrasion and exhibits breccia clasts which can be fit into place. This conforms well with observations from other parts of the Gowganda Formation, where the contact with the underlying formation is sometimes vertical to overhanging and the basal deposit displays an appearance similar to breccia (Miall, 1985). In one area to the southwest (Whitefish Falls area), which has been interpreted to be glaciomarine (Card, 1978; Young \& Nesbitt, 1985), the sediments are brecciated and mixed with mafic magma as peperites (Young et al., 2004). These features would normally be seen as evidence for tectonic action. Tectonism in this case would be considered to be recurrent earthquakes during long time periods, maybe triggered by magmatism and continental breakup, that have been suggested to have occurred during a tectonically active period when the Gowganda Formation was deposited (Young \& Nesbitt, 1985; Eyles, 1993; Melezhik et al., 2013; Young, 2014, 2019). The area was a subsiding basin, with repeating tectonic disturbance, which would transport both intrabasinal and extrabasinal clasts (Eyles, 1993; Young \& Nesbitt, 1985; Young, 2014, 2019). Earthquakes would split the bedrock, trigger gravity flows and explain such sedimentary structures as clastic dikes which have been documented at Cobalt (compare Card, 1978, p. 124). Brecciation may also occur in the basal shear zone below mass flows (Cardona et al., 2020). It is difficult to visualise why a glacier would not abrade the underlying bedrock and not scatter the breccia from at least some of the shallower palaeodepressions.

The process in which rocks are crushed, but where the pieces are still in contact or in near con- 
tact, similar to those which have been documented from the Gowganda Formation, is often described as a "jigsaw puzzle effect" (Scott, 1988a). This feature has not been reported from basal Pleistocene tills (e.g., Ui, 1989; Thompson, 2009), but it has in softer dolomite clasts in the "Great Breccia" in the Precambrian Port Askaig "tillite" in Scotland, and in a graded conglomerate/"tillite" in the Permo-Carboniferous of India (Harker \& Giegengack, 1989; Bose et al., 1992; Harker, 1993). The interpretation that the two latter "tillites" are basal tills has been debated (e.g., Arnaud, 2004). Yet, the "jigsaw puzzle effect" is common in debris flow/avalanche deposits, where different materials mix (Eyles \& Eyles, 2000), including in cohesive debris flows (Costa, 1984; Scott, 1988a; Stoopes \& Sheridan, 1992; Capra \& Macias, 2002; Thompson, 2009).

Mustard \& Donaldson (1987b) interpreted the clast-supported and resedimented diamictites in the area as fan associations. One "missing" facies common to fan associations, which was not described by Mustard \& Donaldson (1987b), is cohesive debris flow deposits. These commonly cannot carry the largest erratics without displaying clear evidence of transport by gravity flow, and 1-3 $\mathrm{m}$ is often the maximum clast size transported by cohesive debris flows (Shepard \& Dill, 1966; Carter, 1975; Middleton \& Hampton, 1976; Costa, 1984; Talling et al., 2012). Redeposited "glaciogenic" sediments often contain larger clasts than "tillites" (Schermerhorn, 1975; Martin, 1981; Young \& Nesbitt, 1985; Fralick \& Miall, 1989). The largest erratic discovered in the Gowganda Formation is $3.4 \mathrm{~m}$ long (Lindsey, 1969) and Young (1981) mentioned a maximum apparent dimension of "about $4 \mathrm{~m}$ ", but these are not in what is considered to be "basal tillite" by any recent researcher. As documented here, clasts in the Gowganda Formation commonly are small, and the larger ones are commonly at the bottom of the sequence. This evidence, as documented both at Cobalt and by other researchers from other areas, favours a sequence that was deposited by gravity flows and not by glacial action.

The sorting of clasts in the formations, vertically and horizontally, and the two main appearances of the clasts, indicates a low-viscosity gravity flow, which would suggest a process similar to the "cement-mixer-model" by Eyles \& Eyles (2000). The evidence indicates that the basal matrix supported "tillite" at Cobalt, which contains mainly small clasts, is "the missing fan facies" and consists of deposits originating from cohesive debris flows. This interpretation would explain the appearance of the complete sedimentary sequence (Table 1), why the "tillite" is clast poor and the largest boulders are at the bottom in the sequence in clast and matrix-supported diamictites. Moreover, it explains why the substratum has been plucked without having been heavily abraded. Plucking may be caused by gravity flows, sometimes even on the face of hard granite (Dill, 1964, 1966; Shepard \& Dill, 1966; Carter, 1975; Stock \& Dietrich, 2006; Dakin et al., 2013). It also explains why the size of the pebbles decreases higher up in the sediments where the sediments would be less cohesive and less compact during transport and deposition of gravity flows (e.g., bDmm, Fl, Frd), and the appearance of flow structures, lonestones and laminated beds. All of these lithological features, and the overall appearance of the deposits (as here described), are common in gravity flow deposits (e.g., Middleton \& Hampton, 1976; Eriksson, 1991; Talling et al., 2007, 2012; Dakin et al., 2013; Shanmugam, 2016). Even if there are superficial similarities, from the evidence described above, the deposits at Cobalt do not display an appearance that is diagnostic of lodgement till, deformation till, any other till, and not even of flow till which is a kind of gravity flow (i.e., the clasts in flow till are still formed by glaciers; compare Hicock \& Dreimanis, 1985, 1992; Dreimanis, 1993). Any evidence of former supraglacial or flow tills would presumably have eroded away, as these are

Table 1. The general superposition, appearance of diamictites and genetic interpretation (at Cobalt, as documented in the present paper).

\begin{tabular}{lll}
\hline \multicolumn{1}{c}{ Vertical succession } & \multicolumn{1}{c}{ Appearance } & \multicolumn{1}{c}{ Interpretation } \\
$\begin{array}{l}\text { Lonestone-bearing } \\
\text { rhythmite }\end{array}$ & $\begin{array}{l}\text { Clastic dikes, load casts, boudins, thick dark "winter" } \\
\text { and thin light "summer" laminae (opposite to true } \\
\text { varves), mm-sized subdivisions, climbing ripples. } \\
\text { Lonestones sorted, evidence of lateral transport, penetra- } \\
\text { tion of laminae rare }\end{array}$ & $\begin{array}{l}\text { Turbidites covering debris-flow } \\
\text { deposits }\end{array}$ \\
$\begin{array}{lll}\text { Clast- and matrix- } \\
\text { supported diamictite }\end{array}$ & Often in streaks or clusters. Clasts often sorted by size \\
$\begin{array}{l}\text { Breccia } \\
\text { Bedrock }\end{array}$ & Clasts often fit into bedrock & $\begin{array}{l}\text { Debrites. Mass flows with more or } \\
\text { less cohesive parts }\end{array}$ \\
\hline
\end{tabular}


commonly less compacted and at the surface. Only the more typical glaciogenic features would stand a chance to be preserved, i.e., those produced over extensive areas. The deposits in the Gowganda Formation are from areas which are not considered to display small patches of less compacted till, and the only part which is considered to be subglacial and not glaciomarine is the one at Cobalt.

\section{Conclusions}

The evidence presented here is summed up in Table 2. During more than a century of research into the Huronian Supergroup, the diamictites in the area have commonly been, more or less by default, interpreted as being glaciogenic, instead of using more objective lithofacies descriptions. This former meticulous research has produced mostly sound geological data which in no way need to be repeat- ed. However, the interpretations have been more or less hampered by a glaciogenic mindset and incomplete knowledge of the appearance of deposits from gravity flows. In the last decades almost all diamictites in the Gowganda Formation have been reinterpreted to be gravity flows or have been interpreted by inductive reasoning to be glaciomarine deposits because they display lonestone clasts which have been interpreted to be dropstones. Conjectural evidence from missing glaciogenic features cannot be used as evidence for glaciation, but only the field evidence which is present at different locations.

The present study reaffirms the interpretation of a gravity flow origin, as based on the evidence in the outcrops of laminated sediments at Cobalt, and junction 129/554, which had previously been interpreted as evidence of glaciation. Furthermore, the evidence from lonestones is at odds with a simple marine/lake rain-out model, and sedimentary

Table 2. Structures and textures of Gowganda Formation deposits for the outcrops which have been studied in the present study, as well as by Molén $(2017,2021)$. Not included in the column are structures that form by non-glaciogenic processes in a glacial environment, e.g., debris flows. Tabulated features are only those that differ significantly between glaciogenic and non-glaciogenic deposits, which also may be present close by or within diamictites worldwide. Conjectural or insignificant (not fully) documented differences from the study area are not tabulated, but discussed in the text only.

\begin{tabular}{|c|c|c|c|}
\hline \multirow{2}{*}{ Feature } & \multicolumn{3}{|c|}{ Origin } \\
\hline & Glacial & $\begin{array}{l}\text { Gravity flow, } \\
\text { tectonic }\end{array}$ & $\begin{array}{c}\text { Gowgan- } \\
\text { da Fm. }\end{array}$ \\
\hline Large areal extent & 2 & 1 & \\
\hline Matrix-supported/fine-grained & 2 & $1-2$ & \\
\hline Sorting/grading & $0-1$ & 2 & Not G \\
\hline Streaks of different sediments & $0-1$ & 2 & Not G \\
\hline Clast/bed thickness correlation & $0-1$ & 2 & \\
\hline Cobbles/boulders & 2 & 2 & \\
\hline$>1-3$ m diameter & 2 & $1-(2)$ & Not G \\
\hline jigsaw fractures & - & 1 & Not G \\
\hline Roches moutonnés/plucked clasts & 2 & $(1)$ & Not G \\
\hline Dropstones/lonestones & 2 & 2 & \\
\hline no fabric & 2 & 1 & \\
\hline weak fabric & 1 & 2 & \\
\hline varied size of clasts & 2 & 1 & Not G \\
\hline good sorting & $0-1$ & $1-2$ & Not G \\
\hline differently compressed laminae & 1 & 2 & Not G \\
\hline no/little penetration & 1 & 2 & Not G \\
\hline laminae thickness changes around the clasts & 1 & 2 & Not G \\
\hline correlation between clast size and sediment thickness & - & 2 & Not G \\
\hline small size compared to other sediments & - & 2 & Not G \\
\hline lee side structures (movement features) & 1 & 2 & Not G \\
\hline penetration of $1 / 3$ clast size & 2 & 1 & Not G \\
\hline Thick dark laminae and thin light laminae within rhythmite & $0-1$ & 2 & Not G \\
\hline Small-scale tectonics (e.g. clastic dikes, water escape structures) within rhythmite & 1 & 2 & Not G \\
\hline
\end{tabular}

- = no example known; 0 = very rare; 1 = less common; 2 = more common; parentheses = very rare or commonly displaying a distinct appearance; Not $\mathrm{G}=$ lack of a glaciogenic feature in the Gowganda Formation. 
structures present next to lonestones indicate transport by gravity flows.

The only "subglacial tillite" that has not been reinterpreted previously, i.e., at Cobalt, displays many geological features that are different from those which have been deposited by glaciers. The main sedimentological and geomorphological features, i.e., the general sedimentary sequence in the outcrops, the irregular subdiamictite bedrock displaying no evidence of glacial erosion, breccia clasts that can be fit into place, sorting of diamictites, and appearance of the lonestone-bearing rhythmites, strongly suggests that the succession studied is non-glacial. Gravity flows triggered by tectonism provide a more natural explanation of the appearance of the sequence (Table 1), i.e., the bedrock, the basal breccia and the appearance of the subsequent beds. This conforms well with the evidence of tectonics and sedimentation from many Precambrian diamictites worldwide, which also could help explain stepwise oxygenation of the Earth's atmosphere resulting from tectonics (Eyles, 1993; Eguchi et al., 2020). The origin of the basal "tillite" is interpreted to be "the missing fan facies" and to have been deposited by cohesive debris flows, possibly as hyperpycnal flows which may be deposited as a full spectrum of gravity flows including cohesive debris flows and rhythmites (Zavala \& Arcuri, 2016; Shanmugam, 2019; Zavala, 2019, 2020).

The overwhelming evidence from the sedimentary and erosional forms and structures from the Coleman Member at Cobalt is at odds with a glacial origin, but instead is similar to what is expected from gravity flow deposits. Hence, climatological inferences based on the traditional genetic interpretation of the Gowganda Formation have only limited or no significance.

\section{Acknowledgements}

This research was partly funded by a travel scholarship from the University of Umeå, Sweden. I wish to thank all reviewers for constructive comments and language corrections.

\section{References}

Al-Hashim, M.H. \& Corcoran, P.L., 2021. Geochemistry of the Paleoproterozoic Espanola Formation, Bruce Mines-Elliot Lake area, Ontario, Canada: implications for provenance, paleo-weathering, and tectonic setting. Geosciences Journal 25, 125-144.
Arnaud, E., 2004. Giant cross-beds in the Neoproterozoic Port Askaig Formation, Scotland: Implications for snowball Earth. Sedimentary Geology 165, 155-174.

Arnaud, E. \& Eyles, C.H., 2004. Glacial influence on Neoproterozoic sedimentation: the Smalfjord Formation, northern Norway - reply. Sedimentology 51, 1423-1430.

Aspler, L.B., Chiarenzelli, R.F., Cousens, B.L., McNicoll, V.J. \& Davis, W.J., 2002. Erratum to "Paleoproterozoic intracratonic basin processes, from breakup of Kenorland to assembly of Laurentia: Hurwitz Basin, Nunavut, Canada" [Sediment. Geol. 141-142 (2001) 287-318]. Sedimentary Geology 151, 335-336.

Atkins, C.B., 2003. Characteristics of striae and clast shape in glacial and non-glacial environments (Ph.D. thesis). Victoria University of Wellington.

Atkins, C.B., 2004. Photographic atlas of striations from selected glacial and non-glacial environments. Antarctic Data Series 28, Victoria University of Wellington.

Bahlburg, H. \& Dobrzinski, N., 2011. A review of the Chemical Index of Alteration (CIA) and its application to the study of Neoproterozoic glacial deposits and climate transitions. [In:] Arnaud, E., Halverson, G.P. \& Shields-Zhou, G. (Eds): The geological record of Neoproterozoic glaciations. Geological Society London, Memoirs 36, 39-50.

Beh, B. \& Fralick, P., 2013. Depositional processes operating on the Paleoproterozoic Gowganda ice margin. [In:] Blaske, A.R. \& Bornhorst, T.J. (Eds): 59th Annual Meeting Institute on Lake Superior Geology, Houghton, Michigan: Proceedings, program and abstracts, pp. 5-6.

Bennett, G., 2006. The Huronian Supergroup between Sault Ste Marie and Elliot Lake. Field Trip Guidebook. vol. 52, part 4. Institute on Lake Superior Geology, Sault Ste Marie, Ontario, 74 pp.

Best, J.L., 1992. Sedimentology and event timing of a catastrophic volcaniclastic mass flow, Volcan Hudson, Southern Chile. Bulletin of Volcanology 54, 299-318.

Bielenstein, H.U. \& Eisbacher, G.H., 1969. Tectonic interpretation of elastic-strain-recovery measurements at Elliot Lake, Ontario. Department of Energy, Mines and Resources, Ottawa, Report R210.

Bose, P.K., Mukhopadhyay, G. \& Bhattacharyya, H.N., 1992. Glaciogenic coarse clastics in a Permo-Carboniferous bedrock through in India: A sedimentary model. Sedimentary Geology 76, 79-97.

Bristow, T.F., Bonifacie, M., Derkowski, A., Eiler, J.M. \& Grotzinger, J.P., 2011. A hydrothermal origin for isotopically anomalous cap dolostone cements from south China. Nature 474, 68-72.

Capra, L. \& Macias, J.L., 2002. The cohesive Naranjo debris-flow deposit $\left(10 \mathrm{~km}^{3}\right)$ : A dam breakout flow derived from the Pleistocene debris-avalanche deposit of Nevado de Colima Volcano (México). Journal of Volcanology and Geothermal Research 117, 213-235.

Card, K.D., 1978. Geology of the Sudbury-Manitoulin area. Districts of Sudbury and Manitoulin. Ontario Geological Survey, Report 166.

Cardona, S., Wood, L.J., Dugan, B., Jobe, Z. \& Strachan, L.J., 2020. Characterization of the Rapanui mass-transport deposit and the basal shear zone: Mount Messen- 
ger Formation, Taranaki Basin, New Zealand. Sedimentology 67, 2111-2148.

Carter, R.M., 1975. A discussion and classification of subaqueous mass-transport with particular application to grain-flow, slurry-flow, and fluxoturbidities. Earth-Science Reviews 11, 145-177.

Carto, S.L. \& Eyles, N., 2012. Sedimentology of the Neoproterozoic (c. $580 \mathrm{Ma}$ ) Squantum 'Tillite', Boston Basin, USA: Mass flow deposition in a deep-water arc basin lacking direct glacial influence. Sedimentary Geology 269, 1-14.

Coleman, A.P., 1908. The Lower Huronian ice age. Journal of Geology 16, 149-158.

Costa, J.E., 1984. Physical geomorphology of debris flows. [In:] Costa, J.E. \& Fleisher, P.J. (Eds): Developments and applications of geomorphology. Springer, Berlin, pp. 268-317.

Crowell, J.C., 1964. Climatic significance of sedimentary deposits containing dispersed megaclasts. [In:] Nairn, A.E.M. (Ed.): Problems in palaeoclimatology. Wiley, London, pp. 86-99.

Dakin, N., Pickering, K.T., Mohrig D. \& Bayliss, N.J., 2013. Channel-like features created by erosive submarine debris flows: field evidence from the Middle Eocene Ainsa Basin, Spanish Pyrenees. Marine and Petroleum Geology 41, 62-71.

Dill, R.F., 1964. Sedimentation and erosion in Scripps Submarine Canyon head. [In:] Miller, R.L. (Ed.): Papers in marine geology. Macmillan, New York, pp. 23-41.

Dill, R.F., 1966. Sand flows and sand falls. [In:] Fairbridge, R.W. (Ed.): The Encyclopedia of oceanography. Reinhold Publ., New York, pp. 763-765.

Domack, E.W., 1990. Laminated terrigenous sediments from the Antarctic Peninsula: the role of subglacial and marine processes. [In:] Dowdeswell, J.A. \& Scource, J.D. (Eds): Glacimarine environments: processes and sediments. Geological Society Special Publication 53, pp. 91-103.

Dowdeswell, J.A., Canals, M., Jakobsson, M., Todd, B.J., Dowdeswell, E.K. \& Hogan, K.A., (Eds), 2016. Atlas of Submarine Glacial landforms: Modern, Quaternary and Ancient. Geological Society Memoirs 46, 618 pp.

Dreimanis, A., 1993. Small to medium-sized glacitectonic structures in till and in its substratum and their comparison with mass movement structures. Quaternary International 18, 69-79.

Eguchi, J., Seales, J. \& Dasgupta, R., 2020. Great Oxidation and Lomagundi events linked by deep cycling and enhanced degassing of carbon. Nature Geoscience $13,71-76$.

Eriksson, P.G., 1991. A note on coarse-grained gravity-flow deposits within Proterozoic lacustrine sedimentary rocks, Transvaal sequence. South Africa. Journal of African Earth Sciences 12, 549-553.

Eyles, C.H. \& Eyles, N., 2000. Subaqueous mass flow origin for Lower Permian diamictites and associated facies of the Grant Group, Barbwire Terrace, Canning Basin, Western Australia. Sedimentology 47, 343-356.

Eyles, C.H., Eyles, N. \& Miall A.D., 1985. Models of glaciomarine sediment and their application to the inter- pretation of ancient glacial sequences. Palaeogeography, Palaeoclimatology, Palaeoecology 51, 15-84.

Eyles, N., 1993. Earth's glacial record and its tectonic setting. Earth-Science Reviews 35, 1-248.

Eyles, N. \& Januszczak, N., 2007. Syntectonic subaqueous mass flows of the Neoproterozoic Otavi Group, Namibia: where is the evidence of global glaciation? Basin Research 19, 179-198.

Eyles, N., Eyles, C.H. \& Miall, A.D., 1983. Lithofacies types and vertical profile models; an alternative approach to the description and environmental interpretation of glacial diamict and diamictite sequences. Sedimentology 30, 393-410.

Fairchild, I.J., Fleming, E.J., Bao, H., Benn, D.I., Boomer, I., Dublyansky, Y.V., Halverson, G.P., Hambrey, M.J., Hendy, C., McMillan, E.A., Spötl, C., Stevenson, C.T.E. \& Wynn, P.M., 2016. Continental carbonate facies of a Neoproterozoic panglaciation, north-east Svalbard. Sedimentology 63, 443-497.

Feng, L.R., Donaldson, J.A. \& Holland, H.D., 2000. Alteration rinds on glacial diamictite clasts in the Gowganda Formation: Possible indicators of low atmospheric oxygen ca. 2.3 Ga. International Geology Review 42, 684-690.

Fralick, P.W. \& Miall, A.D., 1989. Sedimentology of the Lower Huronian Supergroup (Early Proterozoic), Elliot Lake area, Ontario, Canada. Sedimentary Geology 63, 127-153.

Frarey, M.J., 1977. Geology of the Huronian Belt between Sault Ste. Marie and Blind River, Ontario. Geological Survey of Canada Memoir 383, 38-49.

Grotzinger, J.P., Fike, D.A. \& Fischer, W.W., 2011. Enigmatic origin of the largest-known carbon isotope excursion in Earth's history. Nature Geoscience 4, 285292.

Harker, R.I., 1993. Fracture patterns in clasts of diamictitets (?tillites). Journal of the Geological Society 150, 251-254.

Harker, R.I. \& Giegengack, R., 1989. Brecciation of clasts in diamictites of the Gowganda Formation, Ontario, Canada. Geology 17, 123-126.

Hicock, S.R. \& Dreimanis, A., 1985. Glaciotectonic structures as useful ice-movement indicators in glacial deposits: four Canadian case studies. Canadian Journal of Earth Sciences 22, 339-346.

Hicock, S.R. \& Dreimanis, A., 1992. Deformation till in the Great Lakes region: implications for rapid flow along the south-central margin of the Laurentide Ice Sheet. Canadian Journal of Earth Sciences 29, 1565-1579.

Hoffman, P.F., 2013. The Great Oxidation and a Siderian snowball Earth: MIF-S based correlation of Paleoproterozoic glacial epochs. Chemical Geology 362, 143-156.

Howe, T.S., 2015. Investigating potential climatic cycles in glacially-influenced rhythmites of the upper Gowganda Formation using geochemical, rhythmites of the upper Gowganda Formation using geochemical, sedimentological and spectral analyses sedimentological and spectral analyses. Western University, 3264, 159 pp.

Howe, T.S., Corcoran, P.L, Longstaffe, F.J.M, Webb, E.A \& Pratt, R.G., 2016. Climatic cycles recorded in glacially influenced rhythmites of the Gowganda Forma- 
tion, Huronian Supergroup. Precambrian Research 286, 269-280.

Hughes, G.B., Giegengack, R. \& Kritikos, H.N., 2003. Modern spectral climate patterns in rhythmically deposited argillites of the Gowganda Formation (Early Proterozoic), southern Ontario, Canada. Earth and Planetary Science Letters 207, 13-22

Isbell, J.L., Cole, D.I. \& Catuneanu, O., 2008. Carboniferous-Permian glaciation in the main Karoo Basin, South Africa: Stratigraphy, depositional controls, and glacial dynamic. [In:] Fielding, C.R., Frank, T.D. \& Isbell, J.L. (Eds): Resolving the Late Paleozoic Ice Age in time and space. Geological Society of America Special Paper 441, pp. 71-82.

Jackson, T.A., 1965. Power-spectrum analysis of two 'varved' argillites in the Huronian Cobalt Series (Precambrian) of Canada. Journal of Sedimentary Petrology $35,877-886$.

Jansa, L.F. \& Carozzi, A.V., 1970. Exotic pebbles in La Salle Limestone (Upper Pennsylvanian), La Salle, Illinois. Journal of Sedimentary Petrology 40, 688-694.

Jensen, P.A. \& Wulff-Pedersen, E., 1997. Discussion of glacial or non-glacial origin for the Bigganjargga tillite, Finnmark, northern Norway. Geological Magazine 134, 874-876.

Kennedy, K., 2020. The Gowganda Formation. Accessed 09/17/2020. https://planetrocks.utsc.utoronto.ca/ trips/oia_vf1.html

Kennedy, K. \& Eyles, N., 2021. Syn-rift mass flow generated 'tectonofacies' and 'tectonosequences' of the Kingston Peak Formation, Death Valley, California, and their bearing on supposed Neoproterozoic panglacial climates. Sedimentology 68, 352-381.

Kennedy, K., Eyles, N. \& Broughton, D., 2019. Basinal setting and origin of thick $(1.8 \mathrm{~km})$ mass-flow dominated Grand Conglomérat diamictites, Kamoa, Democratic Republic of Congo: Resolving climate and tectonic controls during Neoproterozoic glaciations. Sedimentology 66, 556-589.

Kump, L.R., Melezhik, V.A., Altermann, W., Eriksson, P.G., Lepland, A. \& Young, G.M., 2013. Palaeoproterozoic snowball Earth? [In:] Melezhik, V.A., Kump, L.R., Fallick, A.E., Strauss, H., Hanski, E.J., Prave, A.R. \& Lepland, A. (Eds): Reading the Archive of Earth's Oxygenation, vol. 3: Global Events and the Fennoscandian Arctic Russia - Drilling Early Earth Project. Springer, Berlin, pp. 1097-1099.

Legun, A., 1984. Huronian Stratigraphy and sedimentation in the Cobalt area. Ontario Geological Survey, Open File Report 5508, $60 \mathrm{pp}$.

Le Heron, D.P, Eyles, N. \& Busfield, M.E., 2020. The Laurentian Neoproterozoic Glacial Interval: reappraising the extent and timing of glaciation. Austrian Journal of Earth Sciences 113, 59-70.

Lindsay, J.F., 1968. The development of clast fabric in mudflows. Journal of Sedimentary Petrology 38, 12421253.

Lindsay, J.F., 1970. Depositional environment of Paleozoic glacial rocks in the Central Transantarctic Mountains. Geological Society of America Bulletin 81, 1149-1171.
Lindsey, D.A., 1969. Glacial sedimentology of the Precambrian Gowganda Formation, Ontario, Canada. Geological Society of America Bulletin 80, 1685-1701.

Lowe, D.R., 1988. Suspended-load fallout rate as an independent variable in the analysis of current structures. Sedimentology 35, 765-776.

Martin, H., 1981. The Late Paleozoic Dwyka Group of the South Kalahari Basin in Namibia and Botswana, and the subglacial valleys of the Kaokoveld in Namibia. [In:] Hambrey, M.J. \& Harland, W.B. (Eds): Earth's pre-Pleistocene glacial record. Cambridge University Press, pp. 61-66.

Martinsen, O., 1994. Mass movements. [In:] Maltman, A. (Ed.): The Geological Deformation of Sediments. Springer, Dordrecht, pp. 127-165.

Melezhik, V.A., Young, G.M., Eriksson, P.G., Altermann, W., Kump, L.R. \& Lepland, A., 2013. Huronian-age glaciation. [In:] Melezhik, V.A., Kump, L.R., Fallick, A.E., Strauss, H., Hanski, E.J., Prave, A.R. \& Lepland, A. (Eds): Reading the Archive of Earth's Oxygenation, vol. 3: Global Events and the Fennoscandian Arctic Russia - Drilling Early Earth Project. Springer, Berlin, pp. 1059-1109.

Menzies, J., 2000. Microstructures in diamictites of the Lower Gowganda Formation (Huronian), near Elliot Lake, Ontario: Evidence for deforming-bed conditions at the grounding line? Journal of Sedimentary Research 70, 210-216.

Miall, A.D., 1983. Glaciomarine sedimentation in the Gowganda Formation (Huronian), Northern Ontario. Journal of Sedimentary Petrology 53, 477-491.

Miall, A.D.,1985. Sedimentation on an early Proterozoic continental margin under glacial influence: The Gowganda Formation (Huronian), Elliot Lake area, Ontario, Canada. Sedimentology 32, 763-788.

Middleton, G.V. \& Hampton, M.A., 1976. Subaqueous sediment transport and deposition by sediment gravity flows. [In:] Stanley, D.J. \& Swift, D.J.P. (Eds): Marine sediment transport and environmental management. Wiley, New York, pp. 197-218.

Molén, M.O., 2017. The origin of upper Precambrian diamictites; Northern Norway: A case study applicable to diamictites in general. Geologos 23, 163-181.

Molén, M.O., 2021. Glaciation or not? An analytic review of features of glaciation and sediment gravity flows and a methodology for field research. (Submitted).

Mustard, P.S., 1985. Sedimentology of the Lower Gowganda Formation Coleman Member (Early Proterozoic) at Cobalt, Ontario. Carleton University.

Mustard, P.S. \& Donaldson, J.A., 1987a. Early Proterozoic ice-proximal glaciomarine deposition: The Lower Gowganda Formation at Cobalt, Ontario, Canada. Geological Society of America Bulletin 98, 373-387.

Mustard, P.S. \& Donaldson, J.A., 1987b. Substrate quarrying and subglacial till deposition by Early Proterozoic ice sheet: Evidence from the Gowganda Formation at Cobalt, Ontario, Canada. Precambrian Research 34, 347-368.

Neuendorf, K.K.E., Mehl, J.P.Jr. \& Jackson, J.A. (Eds), 2005. Glossary of Geology. American Geological Institute, Alexandria, $779 \mathrm{pp}$. 
Peakall, J., Best, J., Baas, J.H., Hodgson, D.M., Clare, M.A., Talling, P.T., Dorrell, R.M. \& Lee, D.R., 2020. An integrated process-based model of flutes and tool marks in deep-water environments: Implications for palaeohydraulics, the Bouma sequence and hybrid event beds. Sedimentology 67, 1601-1666.

Popov, L.E., Álvaro, J.J., Holmer, L.E., Bauert, H., Pour, M.G., Dronov, A.V., Lehnert, O., Hints, O., Männik, P., Zhang, Z. \& Zhang, Z., 2019. Glendonite occurrences in the Tremadocian of Baltica: first Early Palaeozoic evidence of massive ikaite precipitation at temperate latitudes. Scientific Reports 9, 7205.

Postma, G., Nemec, W. \& Kleinspehn, K.L., 1988. Large floating clasts in turbidities: a mechanism for their emplacement. Sedimentary Geology 58, 47-61.

Schermerhorn, L.J.G., 1974. Late Precambrian mixtites: Glacial and/or nonglacial? American Journal of Science 274, 673-824.

Schermerhorn, L.J.G., 1975. Tectonic framework of Late Precambrian supposed glacials. [In:] Wright, A.E. \& Moseley, F. (Eds): Ice ages: Ancient and modern. Seal House Press, Liverpool, pp. 241-274.

Schwab, F.L., 1981. Late Precambrian tillites of the Appalachians. [In:] Hambrey, M.J. \& Harland, W.B. (Eds): Earth's Pre-Pleistocene glacial record. Cambridge University Press, pp. 751-755.

Scott, K.M., 1988a. Origin, behavior and sedimentology of prehistoric catastrophic lahars at Mount St. Helens, Washington. [In:] Clifton, H.E. (Ed.): Sedimentologic consequences of convulsive geologic events. Geological Society of America Special Paper 229, pp. 23-36.

Scott, K.M., 1988b. Origins, behavior and sedimentology of lahars and lahar-runout flows in the Toutle-Cowlitz River system. US Geological Survey Professional Paper 1447-A.

Shanmugam, G., 2016. Submarine fans: a critical retrospective (1950-2015). Journal of Palaeogeography 5, 110-184.

Shanmugam, G., 2017. The contourite problem. [In:] Mazumder, R. (Ed.): Sediment Provenance Influences on Compositional Change from Source to Sink. Elsevier, pp. 183-254.

Shanmugam, G., 2019. Reply to discussions by Zavala (2019) and by Van Loon, Hüeneke, and Mulder (2019) on Shanmugam, G. (2018, Journal of Palaeogeography: 'the hyperpycnite problem'. Journal of Palaeogeography 8,31 .

Shepard, F.P. \& Dill, R.F., 1966. Submarine canyons and other sea valleys. Rand McNally, Chicago, 381 pp.

Smith, D.G. \& Bailey, R.J., 2018. Discussion: Howe, T.S., Corcoran, P.L., Longstaffe, F.J., Webb, E.A, Pratt, R.G., 2016. Climatic cycles recorded in glacially influenced rhythmites of the Gowganda Formation, Huronian Supergroup, Precambrian Research. Precambrian Research 315, 324-326.

Stock, J.D. \& Dietrich, W.E., 2006. Erosion of steepland valleys by debris flows. Geological Society of America Bulletin 118, 1125-1148.

Stoopes, G.R. \& Sheridan, M.F., 1992. Giant debris avalanches from the Colima Volcanic Complex, Mexico:
Implications for long-runout landslides (>100 km) and hazard assessment. Geology 20, 299-302.

Tachibana, T., 2013. Lonestones as indicators of tsunami deposits in deep-sea sedimentary rocks of the Miocene Morozaki Group, central Japan. Sedimentary Geology 289, 62-73.

Talling, P.T., Masson, D.G., Sumner, E.J. \& Malgesini, G., 2012. Subaqueous sediment density flows: Depositional processes and deposit types. Sedimentology 59, 1937-2003.

Talling, P.J., Wynn, R.B., Masson, D.G., Frenz, M., Cronin, B.T., Schiebel, R, Akhmetzhanov, A.M., Dallmeier-Tiessen, S., Benetti, S., Weaver, P.P.E., Georgiopoulou, A., Zühlsdorff, C. \& Amy, L.A., 2007. Onset of submarine debris flow deposition far from original giant landslide. Nature 450, 541-544.

Thomas, G.S.P. \& Connell, R.J., 1985. Iceberg drop, dump and grounding structures from pleistocene glacio-lacustrine sediments, Scotland. Journal of Sedimentary Petrology 55, 243-249.

Thompson, N.D., 2009. Distinct element numerical modelling of volcanic debris avalanche emplacement geomechanics. Bournemouth University, $282 \mathrm{pp}$.

Ui, T., 1989. Discrimination between debris avalanche and other volcaniclastic deposits. [In:] Latter, J.H. (Ed.): Volcanic hazards. Springer, Berlin, pp. 201-209.

Walton, A.W. \& Palmer, B.A., 1988. Lahar facies of the Mount Dutton Formation (Oligocene-Miocene) in the Marysvale Volcanic Field, Southwestern Utah. Geological Society of America Bulletin 100, 1078-1091.

Williams, G.E., Schmidt, P.W. \& Young, G.M., 2016. Strongly seasonal Proterozoic glacial climate in low palaeolatitudes: Radically different climate system on the pre-Ediacaran Earth. Geoscience Frontiers 7, 555-571.

Yawar, Z. \& Schieber, J., 2017. On the origin of silt laminae in laminated shales. Sedimentary Geology 360, 22-34.

Young, G.M., 1981. The Early Proterozoic Gowganda Formation, Ontario, Canada. [In:] Hambrey, M.J. \& Harland, W.B (Eds): Earth's pre-Pleistocene glacial record. Cambridge University Press, pp. 807-812.

Young, G.M., 2013. Precambrian supercontinents, glaciations, atmospheric oxygenation, metazoan evolution and an impact that may have changed the second half of Earth history. Geoscience Frontiers 4, 247-261.

Young, G.M., 2014. Contradictory correlations of Paleoproterozoic glacial deposits: Local, regional or global controls? Precambrian Research 247, 33-44.

Young, G.M., 2017. Ice ages in Earth history: Puzzling paleolatitudes and regional provenance of ice sheets on an evolving planet. [In:] Mazumder, R. (Ed.): Sediment provenance: influences on compositional change from source to sink. Elsevier, pp. 533-562.

Young, G.M., 2018. Precambrian glacial deposits: their origin, tectonic setting, and key role in earth evolution. [In:] Menzies, J. \& van der Meer, J.J.M. (Eds): Past glacial environments, Elsevier, Amsterdam, pp.17-45.

Young, G.M., 2019. Aspects of the Archean-Proterozoic transition: How the great Huronian Glacial Event was initiated by rift-related uplift and terminated at the 
riftdrift transition during break-up of Lauroscandia. Earth-Science Reviews 190, 171-189.

Young, G.M. \& Nesbitt, H.W., 1985. The Gowganda Formation in the southern part of the Huronian Outcrop Belt, Ontario, Canada: Stratigraphy, depositional environments and regional tectonic significance. Precambrian Research 29, 265-301.

Young, G.M., Shaw, C.S.J. \& Fedo, C.M., 2004. New evidence favouring an endogenic origin for supposed impact breccias in Huronian (Paleoproterozoic) sedimentary rocks. Precambrian Research 133, 63-74.

Zavala, C., 2019. The new knowledge is written on sedimentary rocks - a comment on Shanmugam's paper "The hyperpycnite problem". Journal of Palaeogeography $8,23$.
Zavala, C., 2020. Hyperpycnal (over density) flows and deposits. Journal of Palaeogeography 9, 17.

Zavala, C. \& Arcuri, M., 2016. Intrabasinal and extrabasinal turbidites: origin and distinctive characteristics. Sedimentary Geology 337, 36-54.

Zimmermann, U., Tait, J., Crowley, Q.G., Pashley, V. \& Straathof, G., 2011. The Witputs diamictite in southern Namibia and associated rocks: constraints for a global glaciation? International Journal of Earth Sciences $100,511-526$.

Manuscript submitted: 21 April 2021 Revision accepted: 14 July 2021 